\title{
Gram Negative Bacteria (Escherichia coli) Win Against Gram Positive Bacteria (Staphylococcus aureus) in The Same Media
}

\author{
Neisya Intan Cahyaningtyas Agung Putri ${ }^{(\mathbb{}}{ }^{\left(\text {Ramadhani }^{2}\right.}{ }^{(\mathbb{1}}$, Eddy Bagus Wasito $^{3^{*}(\mathbb{C}}$ \\ ${ }^{1}$ Faculty of Medicine, Universitas Airlangga, Surabaya, Indonesia \\ ${ }^{2}$ Department of Anatomy, Histology and Pharmacology, Faculty of Medicine, Universitas Airlangga, Surabaya, \\ Indonesia \\ ${ }^{3}$ Departemen of Microbiology, Faculty of Medicine, Universitas Airlangga, Surabaya, Indonesia
}

\section{A R T I C L E I N F O}

\section{Article history:}

Received 23 August 2021

Received in revised form 15

September 2021

Accepted 2 Oktober 2021

Available online 30 October 2021

\section{Keywords:}

E. coli,

S. aureus,

Doubling time.

*) Corresponding author: eddybaguswasito@yahoo.co.id

\begin{abstract}
A B S T R A C T
Introduction: Biodiversity of the microorganism in Indonesia lead to the large amount of patient with infection. Human can get infected in two different place, with different kind of bacteria that cause the infection. This may lead to bacteremia without knowing which bacteria type whose causing it, either the Gram positive or Gram negative bacteria, whereas the treatment of this two types of bacteria are different. The aim of this study is to determine the doubling time of the Gram positive and Gram negative bacteria when they are grown in the same lesion and the kinds of bacteria that we need to eliminate first.

Methods: Staphylococcus aureus and Escherichia coli bacteria were used as samples in this study. Bacterial culture in nutrient broth with 0.5 OD turbidity were mixed then incubated in incubator with $35^{\circ} \mathrm{C}$. Every one hour within 24 hour, $0.01 \mathrm{ml}$ of bacterial culture was taken in serial dilutionover time, varying between $106-1012$. It was then planted in nutrient agar plate with droplets technique. After it had been incubated for 24 hours, we counted the Colony Forming Unit per $\mathrm{ml}(\mathrm{CFU} / \mathrm{ml})$ to time, then the doubling time of the bacteria. The result were then compared between the Staphylococcus aureus and Escherichia coli group.

Results: Two tailed t-test result of the doubling time between Staphylococcus aureus dan Escherichia coli was $<0,05(\mathrm{p}=0,000)$ wich means that there is significant difference of the doubling time between Staphylococcus aureus $(24,35 \pm 2,23$ munites), and Escherichia coli $(18,37 \pm 0,50$ minutes). When grown in the same media, Gram positive bacteria (Staphylococcus aureus) had slower doubling time than Gram negative bacteria (Escherichia coli) as much as 1.32 times.

Conclusion: In bacteremia with two possible kinds of bacterial suspect, we need to eliminate the Gram negative bacteria first.
\end{abstract}

Introduction

Indonesia is a tropical country, hence it has warm temperature and high humidity. This condition is very beneficial for bacterial growth. This causes Indonesia to have a wide variety of bacteria, including Gram positive and Gram negative bacteria. This also causes the variety of types of bacteria and types of infection caused by bacteria in Indonesia.

Of all cases of infection, it was found $53.5 \%$ were GI tract infections, $20.9 \%$ were urinary tract infections, $9.5 \%$ were bacteremia cases, $0.6 \%$ were central nerve infections, of which $94.9 \%$ were caused by Gram positive bacteria and $5.1 \%$ were caused by Gram negative bacteria. ${ }^{1}$ As humans we may have infections in two different places with two different types of bacteria. This condition can cause bacteremia, without knowing which bacteria type was its main cause. Hence, after culturing bacteria from patients who experience bacteremia, we may find Gram positive and Gram negative bacteria in one bacterial culture, one example is Staphylococcus aureus and Escherichia coli. On the other hand, the treatment of these two types of bacteria are also very different.

Based on the reasons above, we conducted this study to 
determine the doubling time of Gram positive and Gram negative bacteria when these two types of bacteria are grown in the same culture, as well as to know the types of bacteria that will be first to eliminated.

Methods

This study is an analytic observational study conducted at the Laboratory of Clinical Microbiology Installation, Diagnostic Center Building, Dr. Soetomo General Academic Hospital from August 2018 - November 2018. Staphylococcus aureus and Escherichia coli bacteria were used as samples in this study. Pure cultures of both types of bacteria were planted into nutrient broth to form bacterial suspensions with $0.5 \mathrm{OD}$ turbidity, then the two bacterial suspensions were mixed and homogenized using vortex and then incubated in incubator at a temperature of $35^{\circ} \mathrm{C}$. Every one hour within 24 hour, 0.01 $\mathrm{ml}$ of bacterial culture was taken then diluted. It was planted in nutrient agar plate quantitatively using a droplet technique, then it was stroke using osse just once. After that, the colony that grown was calculated based on colony forming unit per $\mathrm{ml}(\mathrm{CFU} / \mathrm{ml})$ to time, so then the doubling time can be calculated. The calculation results were compared between the Staphylococcus aureus and Escherichia coli group. Data were analyzed using two tailed t-test for normally distributed data to obtain a significant value.

Results

In incubation results, the colonies from Staphylococcus aureus and Escherichia coli can be distinguished. (Figure 1) Staphylococcus aureus bacterial colonies had a golden yellow color, whereas Escherichia coli bacterial colonies had no color, so the number of colonies to time can be calculated. (attachment 1)

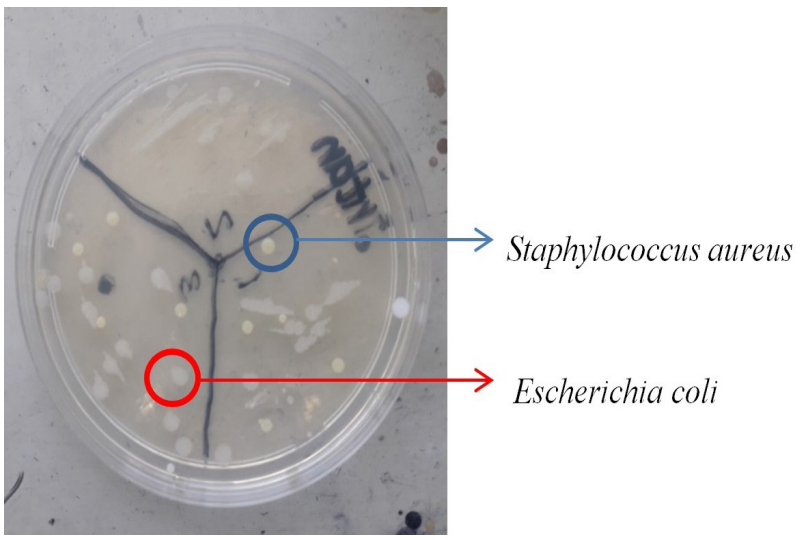

Figure 1. The mix culture incubation results of Staphylococcus aureus and Escherichia coli at $35^{\circ} \mathrm{C}$ for 24 hours

From the data above, Colony Forming Unit / ml (CFU / ml) can be calculated according to the formula. ${ }^{3}$

number of cells per $\mathrm{ml}=$ number of colonies $*$ dilution factor Bacterial growth are presented in the number of bacteria to

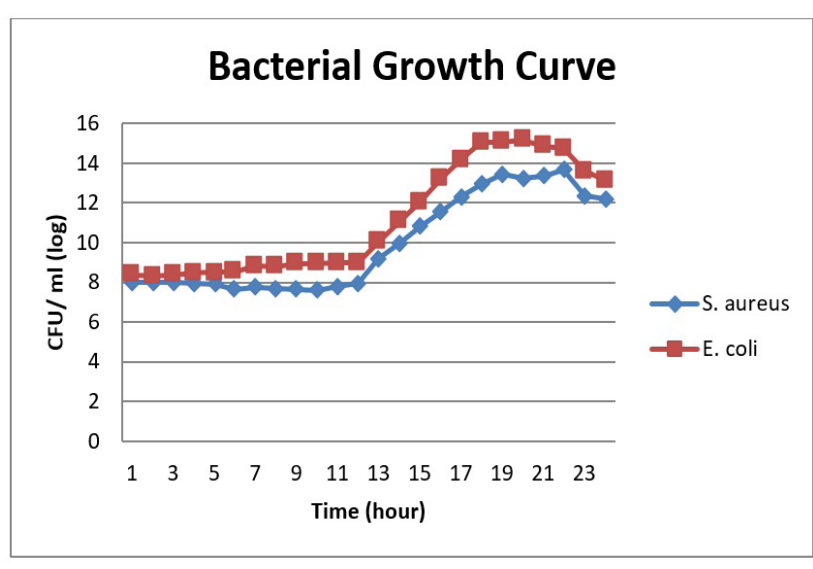

Figure 2. Bacterial Growth Curve To Time

The lag phase lasted from 1-12 hours for Staphylococcus aureus and Escherichia coli. The log phase lasted from 1318 hours for Staphylococcus aureus and Escherichia coli. In the log phase we can calculate the doubling time of Staphylococcus aureus and Escherichia coli using formula. ${ }^{2}$

$$
\begin{array}{ll}
\mathrm{N} & =(\log \mathrm{CE}-\log \mathrm{CO}) / \log 2 \\
\mathrm{GT}) & =\mathrm{t} / \mathrm{N} \\
\mathrm{GT} & =\text { Generation time } \\
\mathrm{t} & =\text { the specified time } \\
\mathrm{CO} & =\text { 0th time cell number } \\
\mathrm{CE} & =\text { Number of cells specified time }(\mathrm{t}) \\
\mathrm{N} & =\text { Number of generations (doublings) }
\end{array}
$$

Doubling time is the average of generation time in one replication during the exponential phase. ${ }^{4}$

The doubling time of Staphylococcus aureus was $24.35 \pm 2.23$ minutes, and doubling time of Escherichia coli was $18.37 \pm 0.50$ minutes. (table 1 )

Table 1. Doubling time frequency distribution

\begin{tabular}{lccc}
\hline & N & $\begin{array}{c}\text { Average } \\
\text { (minutes) }\end{array}$ & $\begin{array}{c}\text { Deviation } \\
\text { Standard }\end{array}$ \\
\hline Staphylococcus aureus & 9 & 24,3589 & 2,23923 \\
\hline Escherichia coli & 9 & 18,3756 & 0,50339 \\
\hline
\end{tabular}

After being analyzed by Shapiro-Wilk test, the result showed that the doubling time data is normally distributed. Comparations were carried out by two tailed t-test and the results that was obtained have a significance of 0.000 , (table 2) which means there is significant difference statistically of the doubling time between Staphylococcus aureus and Escherichia coli. The average doubling time of the two types of bacteria then divided to produce the comparison ratio between the two types of bacteria so the ratio of 1.32 times is produced.

Table 2. The two tailed t-test of doubling time

\begin{tabular}{llccccc}
\hline & & \multicolumn{2}{c}{$\begin{array}{c}\text { Levene s Test for Equality } \\
\text { of Variances }\end{array}$} & \multicolumn{3}{c}{ t-test for Equality of Means } \\
\cline { 2 - 7 } & & $\mathrm{F}$ & $\mathrm{Sig}$ & $\mathrm{t}$ & $\mathrm{df}$ & Sig. (2-tailed) \\
\hline Doubling time & $\begin{array}{l}\text { Equal Variances not } \\
\text { assumed }\end{array}$ & 10.923 & 0.004 & -7.821 & 8.807 & 0.000 \\
\hline
\end{tabular}


The stationary phase lasted from 19-22 hours for Staphylococcus aureus and lasted from 19-20 hours for Escherichia coli. The decline phase lasted from 23-24 hours for Staphylococcus aureus and lasted from 21-24 hours for Escherichia coli.

\section{Discussion}

In the log phase, the doubling time of S. aureus was $24.35 \pm 2.23$ minutes, slightly different from the study by Kaatz and Seo (1995) that found the doubling time of S. aureus was 29-35 minutes. ${ }^{7}$ This may be due to the different types of strains from the $\mathrm{S}$. aureus that was used. Cui et al. (2003) demonstrated different strains of S. aureus also had different doubling times, BR1 strains was 19.53 minutes, while PC strains was the slowest doubling time in 38.94 minutes. $^{8}$ Doubling time of E. coli was $18.37 \pm$ 0.50 minutes, this statement was in accordance with Reshes et al. (2008) where the doubling time of E. coli was $18.1 \pm 0.52$ minutes. ${ }^{9}$ When compared, S. aureus had a slower doubling time compared to E. coli as much as 1.32 times. When 2 different types of bacteria are grown in the same media, bacteria with slower doubling time will experience population lost so that the number of bacteria with slower doubling time will decrease. ${ }^{10}$ As previous study demonstrated $\mathrm{S}$. aureus with slower doubling time is suppressed by E. coli which has faster doubling time. The growth suppression phenomena in the same media might due to the bacteria is not only eat nutrients contained in the media but also "eat" the other bacteria. When there are severe nutritional stresses and there is competition to get nutrients, the bacteria will make intercellular communication to produce a signal molecule so that bacteria will produce toxins or antimicrobials that will kill the other bacteria. The cells that are attacked will release nutrients that can be used as nutrients for other bacteria. To avoid suicide due to toxins or antimicrobials released by the bacteria itself, the bacteria will produce proteins that protect the bacteria themselves from the toxins or antimicrobials they release. ${ }^{11}$ Bacteria with faster doubling time (E. coli) will have a larger amount of CFU/ml while bacteria with slower doubling time (S. aureus) will have a smaller amount of CFU/ml as well. With this difference in number, there is also a difference in the amount of toxin or antimicrobials that will be produced. The more bacteria in there, the more toxins or antimicrobials that will be produced by certain groups of bacteria so that the number of bacteria destroyed by a group of bacteria will also be greater. This is what causes the suppression of the $\mathrm{S}$. aureus by E. coli.

An elongation of lag phase phase was acquired. The lag phase which usually only lasted about 3 hours extended to 12 hours. ${ }^{5}$ This might be due to the need for longer adaptation times. Even an intervention in the media can lead to elongation of the bacterial lag phase. ${ }^{6}$ In addition, lengthening of the lag phase may caused by differences in the types of initial media (mac conkey and blood agar) and growth media in this study (nutrient broth) so that the longer adaptation time is needed. ${ }^{5}$ This study samples that had been stored in the refrigerator were also one of the factors that cause elongation of the lag phase. Nutrient broth that used in this study was also a simple type of media so the nutrients contained are very minimal which also contributes to the elongation of the lag phase which is the adaptational phase.
The stationary phase lasted 2-4 hours where the number of bacteria is relatively constant; this was because the number of bacteria that grown is the same as the number of bacteria that die, which was caused by lack of nutrients or accumulation of toxic metabolic products. ${ }^{12}$

The decline phase was only recorded for 2-4 hours in this study, this was due to the extension of the lag phase which causes the decline phase to occur more than 24 hours. This cell death was due to the accumulation of bacterial metabolites in the form of acidic lactic acid which is not suitable for bacterial growth, without being balanced by the growth of more bacteria because of the amount of nutrients that have been exhausted. ${ }^{5}$

In the case of bacterial infection, practioner are using antibiotics as the main therapy, however overuse or inappropriate use of antibiotic can lead to resistance. ${ }^{13}$ Our result indicates that in which source of infection are from two different Gram and antibiograms types of bacteria (S. aureus and E. coli), it is necessary to consider treating the E. coli first. This is based on the results of this study where Judging from faster doubling time of E. coli that has faster doubling time turned out to be more competitive in the same concentration than $\mathrm{S}$. aureus, so it is most likely that the bacteremia that occurred was caused more by the E. coli.

The limitation of this study is that the results of the culture which were contaminated caused the researchers to have to retest the study. In addition, the bacteria used in this study was bacteria that had been stored in the refrigerator, not a fresh bacteria.

Conclusion

When grown in the same media, Gram-positive bacteria (S. aureus) had slower doubling time than Gram-negative bacteria (E. coli) as much as 1.32 times. A faster doubling time bacteria could produce higher toxins that can kill the competitors.

Conflict of Interest

There is no conflict of interest of this study.

References

1. Janas J, Sutoto S, Punjabi N. Infeksi Komunitas (IK)/ Infeksi Luar Rumah Sakit (ILRS) (Community Acquired Infection) Di Rumah Sakit Khusus Penyakit Menular Jakarta. Buletin. 1992;20(2):67-78.

2. Sudarmadi AAM, Prajitno S, Widodo ADW. Antibiotic Resistance in Escherichia coli and Staphylococcus aureus from Retail Chicken Meat in Surabaya, Indonesia. Biomolecular and Health Science Journal. 2020;3(2):109-113.

3. Cappuccino J.G., Sherman N. Microbiology A Laboratory Manual. 10th ed. United States of America: Pearson Education, Inc; 2014

4. Pelczar Jr M. J, Chan E.C. S. Dasar Dasar Mikrobiologi. Jakarta: UI Press; 2005.

5. Sharah A, Karnila R, Desmelati. Pembuatan Kurva Pertumbuhan Bakteri Asam laktat yang di Isolat dari ikan peda kembung (Rastrelliger sp.). JOM FAPERIKA. 2015;2(2):53-58.

6. Glass K, Loeffelholz J, Ford J, Doyle M. Fate of Escherichia coli O157:H7 as affected by $\mathrm{pH}$ or sodium chloride and in fermented, dry sausage. Applied And Environmental Microbiology. 1992;58(8):2513-2516.

7. Kaatz G, Seo S. Inducible NorA-mediated multidrug resistance in Staphylococcus aureus. Antimicrobial Agents and Chemotherapy. 1995;39(12):2650-2655.

8. Cui L, Ma X, Sato K, Okuma K, Tenover F, Mamizuka E, Gemmell C, Kim M, Ploy M, El-Solh N, Ferraz V, Hiramatsu K. Cell Wall Thickening Is a Common Feature of Vancomycin Resistance in Staphylococcus aureus. Journal of Clinical Microbiology. 2003;41(1):5-14 
9. Reshes G, Vanounou S, Fishov I, Feingold M. Timing the start of division inE. coli: a single-cell study. Physical Biology. 2008;5(4):046001.

10. Ender M, McCallum N, Adhikari R, Berger-Bachi B. Fitness Cost of SCCmec and Methicillin Resistance Levels in Staphylococcus aureus. Antimicrobial Agents and Chemotherapy. 2004;48(6):22952297.

11. Håvarstein L, Claverys J. Cannibalism and fratricide: mechanisms and raisons d'être. Nature Reviews Microbiology. 2007;5:219-229.

12. Greenwood D, Barer M, Slack R, Irving W. Medical Microbiology. 18th ed. Nottingham: Elsevier; 2012.

13. Trisnawati T, Retnowati W, Indiastuti DN. Combination of Red Coconut Coir (Cocos nucifera L. var rubescens) and Linezolid on Methicillin-Resistant Staphylococcus aureus in vitro Growth. Biomolecular and Health Science Journal. 2020;3(1):11-14. 